FILOZOFIA

Roč. 75,2020, č. 9

DOI: https://doi.org/10.31577/filozofia.2020.75.9.5

\title{
O OBJAVOVANÍ A KONŠTRUOVANÍ MOŽNOSTÍ
}

MARTIN SCHMIDT, Filozofická fakulta Univerzity Mateja Bela v Banskej Bystrici, Banská

Bystrica, SR

\author{
SCHMIDT, M.: On Discovering and Construing Possibilities \\ FILOZOFIA, 75, 2020, No 9, pp. $793-803$
}

\begin{abstract}
The aim of the paper is to argue that it is not possible to approach modalities solely on empiric grounds as the followers of Kripke and Putnam maintain. This holds even in the case of nomological possibilities that are rooted in the laws of nature. There are no laws of nature that prevent scenarios opposing reality, for instance, no law precludes the possibility of the evening star not being identical with the morning star. As the paper argues, in order to prevent these scenarios, the concept of nomological possibility must contain some pieces of a priori metaphysics. Put differently, nomic possibilities are not just discovered, nomic possibilities are also construed.
\end{abstract}

Keywords: Nomic possibilities - Logical possibilities - Laws of Nature

\section{Úvod}

Je možné, aby číra tekutina padajúca z oblakov, ktorú denne pijeme, ktorá je bezfarebná a bez chuti, mala iné chemické zloženie ako $\mathrm{H}_{2} \mathrm{O}$ ? Ak áno, znamená to, že voda je len náhodne $\mathrm{H}_{2} \mathrm{O}$ a že by mohla byt' napríklad XYZ? Alebo predstava vody s rozdielnym chemickým zložením je len čírou špekuláciou, ked’že voda je predsa len nevyhnutne $\mathrm{H}_{2} \mathrm{O}$ ? V uvedených otázkach sa vyskytujú výrazy, ktoré vyjadrujú modality možnosti a nevyhnutnosti. Dnešnú analytickú metafyziku si bez témy modalít (kategórií možného, nemožného a nevyhnutného) nevieme predstavit'. Zasiahla viaceré diskusie, spomeňme problematiku esencií, identity, existencie, pretrvávania $\mathrm{v}$ čase a podobne. $V$ druhej polovici dvadsiateho storočia prichádzajú na filozofickú scénu revolučné názory S. Kripkeho (Kripke 1980) a H. Putnama (Putnam 1972), ktoré uvažovanie o modalitách výrazne pozmenili. Revolucionári sa vzdávajú apriórneho prístupu $\mathrm{k}$ modalitám $\mathrm{v}$ prospech aposteriórneho, $\mathrm{v}$ ich videní sú modality skôr empiricky ako teoreticky dané objekty - modality sa nekonštruujú, ale objavujú. Naše vnútorné

\footnotetext{
${ }^{1}$ Ďakujem dvom anonymným recenzentom časopisu Filozofia za to, že ma upozornili na viacero nedopracovaných úvah a viacero terminologických nejasnosti v pôvodnej verzii príspevku.
} 
kognitívne schopnosti nám neprezradia, ktorá molekula je podstatou vody. Z apriórnej úvahy nezistíme, či môže mat' zlato iné atómové číslo ako 79, toto všetko musíme objavit'. Nedávno sa objavilo viacero kontrarevolučných príspevkov predovšetkým z pera D. Chalmersa $(2008,2006)$, ktorý o modalitách uvažuje opät tradične. V jeho chápaní sú modality primárne teoretickými objektmi, ku ktorým máme najmä apriórny prístup, pričom prišiel aj s teoretickým riešením, ktoré by malo zohl'adnit' kritiku S. Kripkeho a H. Putnama na adresu tradičného prístupu. ${ }^{2} \mathrm{~V}$ tomto príspevku však nebudeme diskusiu medzi revolucionármi a kontrarevolucionármi podrobnejšie sledovat'. Zameriame sa na revolučnú tézu o aposteriórnom prístupe $\mathrm{k}$ modalitám a budeme sa venovat' najmä kategórii možnosti. Zaujímat' nás budú nomologické možnosti rešpektujúce zákony prírody, ktoré by mali byt' aposteriórnemu uvažovaniu najbližšie. No aj v ich prípade zistíme, že rýdzo aposteriórne dané nie sú a na to, aby sme ich adekvátne uchopili, potrebujeme aj niektoré apriórne princípy.

\section{Logické a nomologické možnosti}

Pod logickými možnost’ami (LM) budeme v tomto príspevku rozumiet' situácie (fakty, udalosti alebo procesy), o ktorých dokážeme neprotirečivo uvažovat'. ${ }^{3}$ Nič logické nebráni existencii vody s molekulovou štruktúrou $\mathrm{XYZ}$ alebo $\mathrm{H}_{2} \mathrm{O}_{2}$. Aj toto sú logické možnosti, hoci nerešpektujú povahu externej reality. To o nomologických možnostiach (NM) nemôže platit'. Obsah tvrdení o NM okrem neprotirečivosti rešpektuje aj zákony prírody, ako ich poznáme z učebníc fyziky, chémie alebo biológie. Nestačí si vymysliet' logicky neprotirečivý scenár toho, aký by svet mohol byt', tento scenár musí zapadnút aj do nomologických charakteristík externej reality. ${ }^{4}$

Spor medzi tradičným prístupom k modalitám, ktorý dnes reprezentuje najmä D. Chalmers s revolucionármi, je predovšetkým sporom o rýdzo LM. Pod touto kategóriou budeme rozumiet' tie LM, ktoré nie sú NM. Dva príklady takýchto modalít sme spomenuli v súvislosti $\mathrm{s}$ charakterom vody $\mathrm{v}$ úvode tejto časti. Rýdzo logické možnosti sú v očiach revolucionárov výlučným produktom nášho jazyka a myslenia, sú príkladmi falošných hypotéz a dokázaných omylov (Šebela 2008, 367). Nepatria

\footnotetext{
2 Tradičné uvažovanie o modalitách má problém vysvetlit’ nevyhnutnosti, ktoré nespoznávame apriórne, ale aposteriórne (napríklad to, že voda je nevyhnutne $\mathrm{H}_{2} \mathrm{O}$ ). Návrh D. Chalmersa, ako tento problém riešit' $\mathrm{v}$ rámci tradičného uvažovania, tkvie $\mathrm{v}$ koncepcii dvojdimenzionálnej sémantiky (Chalmers 2008).

${ }^{3}$ Ide o vol'nejšie použitie pojmu logickej možnosti, ktoré nie je späté s modalitami definovanými v konkrétnom logickom systéme. Za túto poznámku vd’ačím anonymnému posudzovatel'ovi.

${ }^{4}$ Jestvuje aj alternatívne chápanie predložené K. Finom, podl'a ktorého nie sú nomologické možnosti ukotvené priamo o zákony prírody, ale o povahu prirodzených druhov a vlastností. Toto chápanie však zásadne nemení hlavné závery príspevku, ked’že aj „správanie“ vlastností a druhov musí byt' v súlade s nomologickým profilom externej reality (Fine 2005, 243).
} 
k skutočným modalitám. Tradične uvažujúci autori by namietali. Ved' ako môžu náhodné empirické skutočnosti diktovat', či je konkrétna logická možnost' tá pravá alebo falošná - všetky neprotirečivé scenáre sú na tej istej úrovni (Jespersen, Materna $2002,116,139)$. Povaha externej reality a aj panujúce zákony mohli byt' iné, nie sú nevyhnutné, a v tomto zmysle sú aj rýdzo logické možnosti skutočnými možnost'ami.

Napríklad scenár, v ktorom môže mat' voda hustotu železa (rýdzo logická možnost'), je skutočnou možnost'ou v prípade možného sveta, v ktorom číra tekutina slúžiaca ako základný nápoj nadobúda vysokú mieru hustoty. Scenár je možný, ak naozaj pripustíme, že aktuálny svet a jeho zákony nie sú nevyhnutné, no takéto uvažovanie si vyžaduje podrobnejšie vysvetlenie.

Pluralitu možných svetov akceptujú predovšetkým zástancovia racionalistického prístupu k modalitám, podla ktorých sú modality dané apriórne - modality sú skôr v „našich hlavách“, ako „tam vonku“. V ich uvažovaní je modálny priestor tvorený súhrnom všetkých logicky konzistentných svetov, pričom každý jeden z nich môže hrat' rolu aktuálneho sveta (Jespersen, Materna 2002,116) - náš aktuálny svet nemá privilegované postavenie, je jedným z mnohých. Každému možnému svetu prináleží priestor NM a keby bol aktuálnym svetom svet, v ktorom môže voda za určitých okolností nadobudnút' hustotu železa, tak by voda s takouto hustotou bola prípustnou bola nomologickou alternatívou. Empiricisticky zmýšl'ajúci autori to vidia inak. Možné svety nie sú na tej stej úrovni, klúčové sú tie, ktoré rešpektujú povahu aktuálneho sveta. Zvyšné sú výsledkom našich špekulácií a nevedomosti, a preto úvaha o radikálnej zmene hustoty vody je skôr naším výmyslom a dokázaným omylom ako skutočnou možnost'ou. Modality predsa nie sú úplne „v našich hlavách“. V nasledujúcich častiach príspevku zameriame pozornost' na kategóriu NM, no k empiricistickým a racionalistickým prístupom k poznaniu modalít sa budeme často vracat'.

\section{Zákony prírody}

O nomologických možnostiach vypovedáme pomocou tvrdení, ktorých obsah rešpektuje nomologický charakter externej reality. Ten je daný zákonmi prírody. V čom presne však spočíva obsah pojmu zákona prírody?

$\mathrm{V}$ prvom rade sa jeho chápanie nesmie zamieňat’ so zákonmi, ktoré poznáme z prírodných vied, ked’že ide o filozofický koncept. Na úvod môžeme zákony prírody stotožnit' s prirodzenými regularitami, ktoré vo svete pozorujeme a zaznamenávame. Veda však nestotožní akúkolvek regularitu so zákonom, ale len tú, ktorú v podobe zákona uchopí. Množstvo prirodzených regularít nenadobúda postavenie vedeckého zákona, no vo filozofickom koncepte zákonov prírody je postavenie regularít rovnocenné. Uvažujme napríklad o regularite súvisiacej s rozpúšt’aním soli vo vode. Tento proces predstavuje jeden zo zákonov prírody, ked’že sol' sa za štandardných okolností 
vo vode nevyhnutne rozpustí. No táto regularita nemá status vedeckého zákona, hoci je vedeckými zákonmi vynútená a regulovaná - napríklad zákonmi, ktoré riadia správanie atómov a molekúl. Tieto skutočnosti potvrdzujú potrebu nielen terminologického, ale aj konceptuálneho odlíšenia zákonov prírody od vedeckých zákonov.

Vo filozofii sa stretávame s troma základnými prístupmi k zákonom prírody. Prvým je humovská pozícia, podla ktorej zákony nesúvisia priamo s prirodzenými regularitami, ale skôr s ich opisom, ked’že regularity nie sú zdrojom nevyhnutnosti. $\mathrm{Z}$ dôvodu absencie zdroja prirodzenej nevyhnutnosti túto koncepciu odmietneme a budeme sa venovat' len zvyšným dvom. Jednou z nich je koncepcia známa pod názvom zloženým z priezvisk jej tvorcov, ktorými sú D. Armstrong, F. Dretske a M. Tooley (A-D-T). Títo autori stotožňujú zákony so stavmi vecí vznikajúcich distribúciami nomologických vzt’ahov na univerzálie, pričom doplním, že tento prístup má sympatie najmä $\mathrm{v}$ tábore racionalistov. Na druhej strane je empiricistický prístup zviazaný s dispozičným chápaním zákonov, čo je posledná koncepcia, ktorou sa budeme zaoberat'.

Avizoval som odmietnutie humovského prístupu s poukázaním na absenciu prirodzenej nevyhnutnosti. Tento postoj vychádza z predstavy o svete ako mozaike navzájom nesúvisiacich lokálnych faktov a udalostí (Lewis 1986, ix). Ak v rámci tejto teórie hovoríme o zákonoch, tak sa zmieňujeme len o výsledkoch našej konceptualizácie regularít, ktoré veda $\mathrm{v}$ mozaike lokálnych udalostí identifikovala a ktoré $\mathrm{v}$ rámci svojich teórií systematizuje. Takéto zákony však nemajú potenciál niečo vynucovat' alebo riadit', a preto ak chceme uvažovat' o objektívnej existencii NM, táto koncepcia nie je použitel'ná. Ak zákony nič neriadia alebo nevynucujú, tak nemôžu byt' ani zdrojom modalít, čo je nakoniec aj v súlade s humovským popieraním objektívnej nevyhnutnosti. Inak je to $\mathrm{v}$ prípade dispozičného chápania alebo A-D-T koncepcie, $\mathrm{v}$ ktorých zdroj prirodzenej nevyhnutnosti nájdeme: v prvom prípade sú ním dispozície, $\mathrm{v}$ druhom nomologické vzt'ahy medzi univerzáliami. Začnime naposledy spomenutou koncepciou, ktorú D. Armstrong charakterizuje takto:

Predpokladajme existenciu zákona, podl'a ktorého majú všetky veci s vlastnost'ou F automaticky vlastnost' $G$. F a G sú univerzálie. Medzi F a G nastáva vzt’ah, ktorý nie je vzt’ahom logickej povahy, ale vzt’ahom náhodnej nevyhnutnosti. Tento stav vecí môžeme symbolicky zobrazit’ ako „N(F,G)“ (Armstrong 1983, 85).

Výraz N v N(F,G) zastupuje vzt’ah nomologickej nevyhnutnosti, ktorý je vzt’ahom druhého rádu (Armstrong 1989, 89), ked’že je univerzáliou, ktorú exemplifikujú takisto univerzálie, presnejšie univerzálie prvého rádu (vlastnosti $F$ a G). Stavy vecí typu $N(F, G)$ Armstrong charakterizuje rovnako ako stavy druhého rádu. Tie sa týkajú 
stavov vecí prvého rádu (Armstrong 1989, 88), ked’že nomologicky riadia správanie jednotlivín, ktoré sú nositel'mi príslušných vlastností spojených vzt’ahom nomologickej nevyhnutnosti.

Povahu vzt’ahu N výstižne charakterizujú atribúty modálnej flexibility a temporálnej rigidnosti (Duží, Jespersen, Materna 2010, 411). Modálne je flexibilný preto, že jeho distribúcia na univerzálie nie je vecou nevyhnutnosti, ale len náhody, čo potvrdzuje existencia možných svetov s rozdielnymi nomologickými charakteristikami (Armstrong 1983, 87). No ak už daný svet svoju nomologickú charakteristiku má, tak ju má nevyhnutne, teda v priestore všetkých myslitel'ných časových okamihov alebo intervalov príslušného sveta sa jeho zákony nemenia. Preto M. Duží, B. Jespersen a P. Materna tento prístup pokladajú za prístup vedúci len $\mathrm{k}$ miernej forme nomologickej nevyhnutnosti. V našom svete vstupujú vlastnosti kyslíka a vlastnosti vodíka do takých nomologických väzieb, ktoré im umožnia utvorit' molekulu $\mathrm{H}_{2} \mathrm{O}$. Tá je realizovaná $\mathrm{v}$ podobe čírej tekutiny padajúcej z oblakov a slúžiacej ako základný nápoj. Pritom v žiadnej temporálnej fáze nášho sveta nedochádza k porušeniu týchto väzieb, no ako sme pred chvíl'ou uviedli, v modálnom kontexte je to inak. Tie isté vlastnosti môžu získat' odlišné nomologické postavenie, pričom na vytvorenie tej istej tekutiny by mohli tvorit' molekulu $\mathrm{H}_{2} \mathrm{O}_{2}$ namiesto molekuly $\mathrm{H}_{2} \mathrm{O}$. Čo je však v našom kontexte ovel'a dôležitejšie, v rámci A-D-T môžu byt' aj svety s odlišnými nomologickými charakteristikami dostupné nášmu svetu - môžu byt' jeho objektívnymi alternatívami. Armstrong je striktný aktualista, odmieta existenciu jednotlivín a univerzálií, ktoré nejestvujú (v prípade jednotlivín), respektíve ktoré nie sú realizovatelné (v prípade univerzálií) v aktuálnom svete (Armstrong 1989, 54; 1983, 8 -9). Z tohto dôvodu je vzt’ah nomologickej nevyhnutnosti distribuovatel'ný výlučne na usporiadané $n$-tice univerzálií aktuálneho sveta, pričom je rovnako dôležité, že tieto distribúcie majú charakter kombinatorických distribúcií (Armstrong 1989, 90), teda apriórne daných možností.

Tieto predpoklady vedú $\mathrm{k}$ dvom kl'účovým záverom: 1) zákony prírody nie sú nevyhnutné, teda existujú možné svety s alternatívnym nomologickým profilom, ktoré sú nám zároveň dostupné; 2) svety s alternatívnymi zákonmi sú rozpoznávané najmä našimi vnútornými kognitívnymi schopnost’ami, a to vd’aka apriórne daným kombinatorickým možnostiam distribúcie vzt’ahu nomologickej nevyhnutnosti na usporiadané $n$-tice univerzálií, pričom apriórny charakter je jedným z podstatných znakov racionalistického prístupu k modalitám. Vzájomná dostupnost' nomologicky možných svetov je založená na skutočnosti, že alternatívy vychádzajú z presne tej istej bázy univerzálií, ktorú máme v aktuálnom svete. Rozdiel je len v distribúcii nomologickej nevyhnutnosti na usporiadané $n$-tice tejto bázy. 
Inak o vzt'ahu dostupnosti uvažujú zástancovia dispozičného chápania zákonov prírody, ked’že nomologická nevyhnutnost' ukotvená o dispozície už nie je náhodne nevyhnutná, ako to je $\mathrm{v}$ rámci A-D-T koncepcie. Je nevyhnutná $\mathrm{v}$ absolútnom zmysle (nielen v temporálnom, ale aj modálnom), a to v súlade s líniou Kripkeho a Putnamovho uvažovania o tzv. prirodzených nevyhnutnostiach. Všimnime si niektoré aspekty dispozičného prístupu podrobnejšie.

Ak vlastnost' $P$ dáva objektu $a$ dispozíciu $D$ vstupovat' do kauzálnej interakcie $I$, potom každý objekt typu $a$, pokial' je nositel'om vlastnosti $P$, má rovnakú dispozíciu. A každý objekt typu $a$, pokial' je nositel'om vlastnosti $P$, vstupuje do kauzálnej interakcie $I$, ak je dispozícia $D$ pod vplyvom relevantného stimulu $S$. Predmet $a$ vstúpi do $I$ v dôsledku manifestácie dispozície $D$, ktorú vyvolala prítomnost' stimulu $S$. Napríklad ionizačná energia medi $745,5 \mathrm{~kJ} \cdot \mathrm{mol}^{-1}$ dáva minerálom medi dispozíciu reagovat' s vodou a $\mathrm{CO}_{2}$, a preto minerály medi nevyhnutne $\mathrm{v}$ každom možnom svete s týmito látkami reagujú, čoho výsledkom je proces ich zvetrávania. Tvrdenia „Každý objekt typu $a$, pokial' je nositel'om vlastnosti $P$, má dispozíciu vstupovat' do interakcie $I$.“, alebo „Každý objekt typu $a$, pokial' je nositel'om vlastnosti $P$, vstúpi do interakcie $I$, pokial' je pod vplyvom $S$ “ hovoria o prirodzených, a zároveň nevyhnutných regularitách nomologického charakteru. Ich pravdivost’ nie je náhodná, vyjadrujú konkrétne prípady prirodzených nevyhnutností. Tieto úvahy však zohl'adňujú špecifické chápanie vlastností v rámci dispozičného prístupu, podl'a ktorého je vlastnost' totožná s dispozíciou, ktorá nositelovi danej vlastnosti umožňuje participovat' na konkrétnych kauzálnych interakciách. Tento predpoklad je však terčom častej kritiky najmä zo strany racionalistov. Predsa si vieme predstavit' taký možný svet, v ktorom jestvujú minerály medi, jestvuje v ňom voda a $\mathrm{CO}_{2}$, no minerály medi nezvetrávajú. Podla koncepcie, ktorú zastávajú A-D-T, je vzt'ah medzi med’ou a jej minerálmi na jednej strane a dispozíciami reagovat's vodou a $\mathrm{CO}_{2}$ na druhej strane vzt'ahom náhody, nie nevyhnutnosti. Prirodzené druhy vecí, akými sú kyslík, med', vodík a uhlík, môžu $\mathrm{v}$ iných svetoch vstupovat' do odlišných nomologických vzt'ahov ako $\mathrm{v}$ našom. Z tohto pohl'adu by mala byt' dispozícia minerálov medi zvetrávat' záležitost'ou náhody, teda je relatívnym prírodným fenoménom, ktorý nepreniká celým logickým priestorom, a to isté platí aj o zákonoch, ktoré takéto správanie minerálov vo vzt’ahu s prostredím regulujú. Zástancovia dispozičného chápania s takýmto vysvetlením nemôžu súhlasit', ked’že v ich metafyzickom obraze je vzt'ah medzi vlastnost'ou a príslušnou dispozíciou vzt'ahom identity - ionizačná energia $\mathrm{v}$ hodnote $745,5 \mathrm{~kJ} \cdot \mathrm{mol}^{-1}$ je nevyhnutne to, čo okrem iného umožňuje aj zvetrávanie minerálov medi. Táto vlastnost' výrazne ovplyvňuje dispozičný profil daného prvku a nech by fyzikálne a chemické vlastnosti prvku $x$ akokol'vek pripomínali med', no $x$ by príslušnou kvantitou ionizačnej energie nedisponovalo, $x$ nemôže byt' med'ou v žiadnom možnom svete. Je 
to podobná situácia ako s vodou a jej molekulou v Putnamovom myšlienkovom experimente s dvojčat’om Zeme (Putnam 1972, 139 - 141).

\section{Nomologicky prípustné možnosti}

$\mathrm{V}$ empiricistickom prístupe $\mathrm{k}$ možnostiam očakávame odmietavý postoj $\mathrm{k}$ rýdzo logickým situáciám a scenárom. Lenže odvolávat' sa na zákony prírody nemusí na naplnenie tohto očakávania stačit'. A-D-T koncepcia je založená na kombinatorických distribúciách vzt'ahu nomologickej nevyhnutnosti na báze existujúcich univerzálií. $\mathrm{V}$ jej rámci priestor nomologických modalít predstavuje len jednu z kombinatorických distribúcií, a to tú, ktorá sa realizuje v aktuálnom svete. Lenže kombinatorických možností je ovel'a viac a v mnohých z nich nájdeme rýdzo logické možnosti vyplývajúce z alternatívnych zákonov prírody, ktoré A-D-T pozná. A-D-T totiž pripúšt’a pluralitu možných svetov vrátane takých, v ktorých má napríklad zlato atómové číslo 80 . V očiach empiricistov je to už rýdzo logická možnost', ktorú by označili za dokázaný omyl.

Teraz je vhodný okamih pouvažovat' o povahe koncepcie A-D-T a položit' si otázku, aký obraz o zákonoch prírody nám vlastne ponúka. Ide jej najmä o „technické“ objasnenie pôvodu objektívnej nevyhnutnosti, ktoré nachádza v distribúciách vzt’ahu N. Tento návrh sám osebe nemusí viest' k rýdzo logickým možnostiam. Keby distribúcie vzt’ahu $\mathrm{N}$ na bázu univerzálií rešpektovali poznatky z dobre fungujúcich vedeckých hypotéz a teórií, boli by rýdzo logické možnosti vylúčené. Lenže A-D-T takto ku vzt’ahu $\mathrm{N}$ nepristupuje, ked’že jeho distribúcii ponecháva v podstate ničím neobmedzené kombinatorické možnosti. Myslím si, že spoliehat' sa na kombinatoriku namiesto vedy je len dôsledkom racionalistickej pozície, ktorú však z A-D-T môžeme odstránit' a celú koncepciu interpretovat' $\mathrm{v}$ duchu empiricizmu. Takáto interpretácia by z pôvodných kombinatorických možností distribúcie vzt’ahu $\mathrm{N}$ na univerzálie ukrojila len nepatrnú čast', a to tú, ktorá rešpektuje platné nomologické väzby. Žial', ani táto verzia A-D-T nie je voči rýdzo logickým modalitám úplne imúnna, ale presne to isté platí aj o chápaní priestoru NM, založeného na dispozičnom prístupe $\mathrm{k}$ zákonom prírody. Aký je dôvod?

Dôvod súvisí so skutočnost’ou, že samy zákony prírody - bez ohl'adu na to, či ich interpretujeme v línii empirickej A-D-T alebo dispozičného chápania-, pripúšt’ajú aj rýdzo logické možnosti. Empiricisti veria, že povaha externej reality výrazne zasahuje do nášho jazyka a následne aj do našich úvah o modalitách. Ako príklad ich prístupu uved'me princípy nevyhnutnosti identity a pôvodu, ktorým sa S. Kripke venoval 
najmä v tretej prednáške, ktorá je súčast’ou filozofickej klasiky Pomenovanie a nevyhnutnost' (Kripke 1980, 111 - 115). ${ }^{5}$ Objavili sme, že najjasnejšie teleso na rannej oblohe je identické s najjasnejším telesom na večernej oblohe. Pre zjednodušenie úvahy označme prvé teleso s vlastným menom Zornica a druhé telesom s vlastným menom Večernica. V súlade s kripkeovským uvažovaním platí, že nejestvuje možný svet, v ktorom by Večernica nebola Zornicou. Táto nemožnost' je absolútna, no problémom je, že zákony prírody ju pripúštajú. Myslím si, že nič logické no ani nomologické nebráni predstave o odlišnom obehu planét v našej sústave. Žiadny zákon prírody nebráni tomu, aby najjasnejšou planétou na rannej oblohe bola iná planéta ako tá istá na večernej oblohe, hoci z perspektívy Kripkeho a jeho nasledovníkov ide o rýdzo logickú možnost', špekuláciu alebo dokázaný omyl. Podobný nesúlad nastáva aj v prípade princípu nevyhnutnosti pôvodu. Podla Kripkeovského uvažovania nie je možné napríklad to, aby ste sa narodili iným rodičom, no opät', ktoré zákony prírody si vynútili, aby konkrétna dvojica muža a ženy bola rodičom konkrétneho potomka? Z týchto príkladov vyplýva, že zákony prírody v rámci empirickej verzie A-D-T a aj dispozičného chápania nie sú voči možnostiam dostatočne reštriktívne. Medzi NM pripustia aj rýdzo logické situácie, čo je z empiricistickej perspektívy vážny nedostatok. Ako to napravit' a rýdzo logické možnosti z priestoru NM definitívne vylúčit?

\section{Nomologické možnosti a apriórne princípy}

Teraz sa dostávame $\mathrm{k}$ hlavnej myšlienke príspevku, podl’a ktorej výlučne aposteriórny prístup k skúmaniu nomologických možností nepostačuje. Musí byt' doplnený niektorými apriórnymi princípmi, čo znamená, že ani nomologické možnosti nie sú len predmetom objavovania, ale aj konštruovania. Nepredložím originálne riešenie, ked’že úlohu chýbajúcich prvkov v obraze NM úspešne zvládnu aj špecifické druhy nevyhnutností, ktoré S. Kripke navrhol v prípade jednotlivín a prirodzených druhov v tretej prednáške (Kripke 1980). ${ }^{6}$ O dvojici z týchto nevyhnutností sme už hovorili, teraz spomeňme aj tie zvyšné. Nevyhnutnost' identity a pôvodu doplňme o nevyhnutnost' rozdielu, nevyhnutnosti materiálnej konštitúcie a materiálneho pôvodu, nevyhnutnost' vlastností prirodzených druhov a nevyhnutnost' príslušnosti k prirodzenému druhu. Ak už v prípade jednotlivín identita nastala, potom je nevyhnutná (nevyhnutne Večernica $=$ Zornica); ak niekde nastal rozdiel, tak aj ten je nevyhnutný (nevyhnutne Večernica $\neq$ Jupiter). Takto uvažujú empiricisti, podl’a ktorých identitu objavujeme, a takýto objav následne ovplyvňuje aj používanie jazyka. Na význam vlastného mena

\footnotetext{
${ }^{5} \mathrm{~V}$ nasledujúcej časti príspevku uvedieme, že ani jeden z týchto princípov nebol empiricky objavený, čo dokazuje, že rýdzo aposteriórny prístup k modalitám sa nehodí ani ku Kripkemu.

${ }^{6}$ Detailnú, a zároveň kritickú analýzu takzvaných kripkeovských nevyhnutností čitatel' nájde v tretej kapitole (Ahmed 2007).
} 
Večernica má vplyv skutočnost', že neoznačuje planétu Jupiter. Nejestvuje možný svet, v ktorom by bola Večernica Jupiterom. Alebo inak povedané, keby sa aj z nejakého dôvodu stal najjasnejším objektom večernej oblohy Jupiter, nemohol by byt' Večernicou. Podobne ako kvapalina XYZ, ktorá nemôže byt' vodou, a to aj napriek tomu, že je číra, bezfarebná, bez chuti a plní úlohu základného nápoja. Analogicky uvažujú empiricisti aj o zvyšných prípadoch Kripkeho nevyhnutností. Ak už raz má daná jednotlivina svoj pôvod v konkrétnej matérii, alebo ak má konkrétne zloženie, alebo ak prináleží ku konkrétnemu druhu atd'., tak tieto skutočnosti majú charakter absolútnych nevyhnutností.

Aby však nedošlo k nedorozumeniu, netvrdím, že predstava Jupitera ako najjasnejšej planéty na večernej oblohe alebo predstava, že som sa narodil iným rodičom, je chiméra. Nie, aj toto sú možnosti, no nereflektujú podstatné empirické objavy tak, ako to od nomologických možností očakávame. $Z$ tohto dôvodu sa im musíme v priestore NM vyhnút', čo docielime použitím uvedených princípov. Týmto spôsobom vylúčime z priestoru NM tie prípady, ktoré vedú $\mathrm{k}$ nesúladu s objavenými nevyhnutnost’ami. Len tak dokážeme zabezpečit' súlad NM s externou realitou, ktorému prítomnost' rýdzo logických možností bráni.

Môže však konštruovanie priestoru NM prijat' Kripkeho nevyhnutnosti? Sami osebe totiž empirický pôvod nemajú. Empiricky povahu vody zistíme, no to, že voda je bezpodmienečne $\mathrm{H}_{2} \mathrm{O}$, a to v každom myslitel'nom svete, už poznatok empirickej povahy nie je. Patrí do sféry apriórnej metafyziky, nijako sme ho neobjavili. Aj tak sa oň empiricisti opierajú a ako tvrdíme v tomto príspevku, o Kripkeho nevyhnutnosti sa musia empiricisti opierat' aj v prípade NM. Čo táto skutočnost' dokazuje? Ako prvé by sme mohli zopakovat', že aj NM sú do určitej miery teoretickými konštruktmi. Osobne si však myslím, že postavenie a úlohu apriórnych princípov nemožno precenit'. Pri chápaní NM nehrajú až takú konštitutívnu rolu ako napríklad povaha externej reality a jej zákony. Ich aplikácia v poznaní automaticky neznamená definitívny rozchod s empiricizmom.

Podobne, hoci v mierne odlišných kontextoch, uvažujú o Kripkeho nevyhnutnostiach vo vzt'ahu k empiricky daným (objektívnym) modalitám aj A. Mallozziová (2018) s T. Williamson (2016). A. Mallozziová tvrdí, že z poznania podstát jednotlivín alebo prirodzených druhov nemôžeme bezprostredne odvodit' modálne tvrdenia (prvá a štvrtá čast' v Mallozzi 2018). Z empirického zistenia, že voda je $\mathrm{H}_{2} \mathrm{O}$, nedokážeme bezprostredne odvodit' modálne tvrdenie, že je to tak nevyhnutne. Na to potrebujeme jednu z Kripkeho nevyhnutností: ak je už raz daná látka konštituovaná konkrétnou štruktúrou, tak je ňou konštituovaná nevyhnutne. Kripkeho nevyhnutnosti plnia úlohu medzičlánkov, ktoré v úvahách A. Mallozziovej premost'ujú podstaty (esencie) s modalitami. T. Williamson hovorí už priamo o zákonoch prírody a uvažuje 
o ich vzt'ahu k metafyzickým a nomologickým modalitám, pričom upozorn̆uje na potrebu zohl'adnenia Kripkeho princípov nevyhnutnosti identity a rozdielu (Williamson 2016, 463). Podobná úvaha je formulovaná aj v tomto príspevku: priestor NM nevieme priamo zo znalosti zákonov prírody odvodit'. Zákony prírody potrebujeme nejakým spôsobom premostit's nomologickými modalitami, pričom vhodné premostenie aj v tomto prípade predstavujú Kripkeho nevyhnutnosti súvisiace $\mathrm{s}$ jednotlivinami a prirodzenými druhmi.

\section{Záver}

Zistili sme, že krajné empiricistické postoje k modalitám sú neobhájitel'né - modality nemožno výlučne objavovat', musíme ich do istej miery aj konštruovat'. No v podobnej situácii sú aj krajne racionalistické prístupy. Aj racionalista potrebuje určitú dávku empírie, aj racionalista vie rozlíšit', čo je, a čo už nie je rýdzo logická možnost'. Nevie to s absolútnou istotou, ale rovnako je na tom aj empirik, ked’že naša veda absolútnym a úplným poznaním nedisponuje. Len úplné a absolútne poznanie by nám umožnilo pri každej posudzovanej modalite jednoznačne určit', či sa pohybuje v rámci nomologických modalít, alebo ich už prekračuje.

Z týchto skutočností však nemožno usúdit', že by sa rozdiely medzi empiricisticky a racionalisticky uvažujúcimi autormi rozplynuli. Aj ked' empiricisti použijú určité prvky apriórneho uvažovania, nič to nezmení na ich odmietavom postoji k rýdzo logickým modalitám. Dichotómia nad’alej pretrváva: bud' ste empiricista a odmietate rýdzo logické možnosti (hoci akceptujete aj isté prvky apriórneho uvažovania), alebo ste racionalistom a rýdzo logické možnosti prijímate (hoci empirický zdroj poznania úplne neodmietnete). Skúmanie toho, ktorá z uvedených alternatív je správna, však presahuje rozsah tohto príspevku.

\section{Literatúra}

AHMED, A. (2007): Saul Kripke. Continuum. London.

ARMSTRONG, D. M. (1983): What Is a Law of Nature? Cambridge: Cambridge University Press. ARMSTRONG, D. M. (1989): A Combinatorial Theory of Possibility. Cambridge: Cambridge University Press.

DUŽÍ, M., MATERNA, P. (2012): TIL jako procedurálni logika. Prưvodce zvídavého čtenáře Transparentni intensionální logikou. Bratislava: Aleph.

DUŽÍ, M., JESPERSEN, B., MATERNA, P. (2010): Procedural semantics for hyperintensional logic: foundations and applications of transparent intensional logic. Dordrecht: Springer.

FINE, K. (2005): Modality and Tense: Philosophical Papers. London: Clarendon Press.

CHALMERS, D. (2008): Two-Dimensional Semantics. In: Lepore, E. - Smith, B. (eds.): Oxford Handbook of Philosophy of Language. Oxford: Oxford University Press, 575 - 607.

CHALMERS, D. (2006): The Foundations of Two-Dimensional Semantics. In: Garcia-Carpintero, M. - Macia, J. (eds.): Two-Dimensional Semantics: Foundations and Applications. Oxford: Oxford University Press, 55 - 140. 
JESPERSEN, B., MATERNA, P. (2002): Are Wooden Tables Necessarily Wooden? Intensional Essentialism Versus Metaphysical Modality. In: Acta Analytica, 17, (1), 115 - 150.

KRIPKE, S. (1980): Naming and Necessity. Cambridge (MA): Harvard University Press.

LEWIS, D. K. (1986): Philosophical Papers. Volume II. New York: Oxford University Press.

MALLOZZI, A. (2018): Two Notions of Metaphysical Modality. Synthese. [online] Dostupné na: https://doi.org/10.1007/s11229-018-1702-2 (Navštívené: 1. 2. 2020).

PUTNAM, H. (1972): The Meaning of 'Meaning'. Minnesota Studies in the Philosophy of Science, $7,131-193$.

ŠEBELA, K. (2008): TIL a esencialismus. Organon F, 15, (3), $358-368$.

WILLIAMSON, T. (2016): Modal Science. Canadian Journal of Philosophy, 46, (4 - 5), 453 - 492.

Táto práca vznikla v rámci projektu VEGA 1/0531/20 Reprezentácia - jej povaha a význam pre poznanie.

Martin Schmidt

Univerzita Mateja Bela v Banskej Bystrici

Filozofická fakulta

Tajovského 40

P. O. BOX 263

97401 Banská Bystrica

Slovenská republika

e-mail: martin.schmidt@umb.sk 